first be endorsed by the political committee and then by the General Assembly as a whole.

\section{Marketing is King}

THE British engineering industry must give greater attention to marketing. This was the message delivered by the managing director of Massey Ferguson (UK), Mr J. W. Beith, in his lecture last week to the Institute of Mechanical Engineers.

Of the 14,992 engineering establishments in Britain, six hundred, or 4 per cent, account for two-thirds of the industry's total exports. An NEDC report in 1965 indicated that the probable rate of return on new investments in the engineering industry has been between 6 and 8 per cent during a period when the acceptable break-even rate was regarded as 15 per cent. Figures such as these, and the high import levels of foreign machine tools, indicate that some manufacturers fail to exploit in the market place the undoubted technical expertise which they possess.

Marketing, Mr Beith declared, should be the paramount activity in a company's operations, and must antedate and determine even the discovery in the research laboratories. If a product is to be tailored to its market, the whole strategy of a firm must be oriented towards the complex of research and planning activities which constitute marketing. Market research includes studies of such factors as the political and economic influences on a market, the demographic trends, the distribution of incomes and expenditures, and the likely appeal of alternative products. These findings form the basis for market planning, the function of which is to specify the product which will most profitably meet the situation described by market research. Market planning defines the physical characteristics of the product, its price, utility and styling; only then can design and manufacture begin, and any afterthoughts will be increasingly expensive. The goal of market planning is to strike the best balance between minimizing unit production costs and maximizing market appeal.

"The future of large sectors of engineering production," Mr Beith said, "will be influenced by the impact of marketing on engineering firms, and by the changes which it will bring about within those firms." The increasing importance of marketing is likely to favour the large firm against the small and to lead to fewer and larger firms. But perhaps the greatest change as firms become more market oriented, Mr Beith suggests, is that engineers will be expected to work within the parameters of the marketing approach and to think in terms not of the product itself but of its marketability.

\section{Parliament in Britain}

\section{Nuclear Power}

AskeD what effect the proposed reductions in capital spending by the nationalized industries would have on the construction of nuclear power stations, Mr Richard Marsh, the Minister of Power, replied that the start of one power station would probably be deferred. (Written answer, December 18.) At question time on the following day, $\mathrm{Mr}$ Wedgwood Benn, the Minister of Technology, defended his decision to close the Culham Establishment, set up for research into the generation of electricity by means of fusion. He said that that programme was well over the horizon, perhaps as much as 25 years ahead. As for the proposal, put to him by Mr David Price, that he transfer Culham from the Atomic Energy Authority to the Science Research Council, he said that work on astrophysics at Culham was to be undertaken by the SRC, and that he was taking Mr Price's proposals seriously.

\section{Sonic Booms}

THE subject of sonic booms came up in both written and oral questions on December 19. The Minister of State for the Ministry of Technology, Mr Stonehouse, said that no decision had been made about restrictions to be placed on the speed of the Concorde airliner over inhabited areas. He estimated that the total market for the aircraft would be reduced to 65 per cent if a ban were to be imposed on the making of supersonic booms overland. Mr Stonehouse went on to say that he did not think it would be wise to start international discussions on supersonic flight over land. Britain, he said, was in touch with France and the United States and would co-ordinate with them in any decision. Nobody could be certain about the characteristics of the bang from Concorde until the aircraft was flying, but there was a great deal that could be learned, and was being learned, from the intensive tests carried out in the United States. In written replies to questions put to him by members, Mr Stonehouse said that the Ministry of Technology would shortly issue a statement about the July sonic boom tests. Thirteen local authorities had commented on various aspects of these tests.

\section{American Aircraft Imports}

IN a written answer, Mr Stonehouse gave figures for the trade in aircraft and space products between Britain and the United States in the first ten months of this year. Britain imported $£ 64,541,000$ worth of aircraft, exporting $£ 37,645,000$ worth to the US. Mr Stonehouse thought that the export prospects of the aircraft industry would be enhanced as a result of devaluation. A Procurement Committee had been established under the British National Export Council and the Confederation of British Industries with the object of securing orders within the aerospace and avionics fields. (Written answer, December 20.)

\section{Civil Defence Warning System}

Lord Stonham, Minister of State, Home Office, in a debate in the House of Lords, gave details of the warning system which would be used to alert the civil population in the event of war. He claimed that the warning system was virtually instantaneous and nation-wide. There were two types of warning signal. The first was a siren similar to that used in the last war. The difference was that the system would now be operated centrally, and warning would be communicated within 30 seconds to 22,000 different points. Each warning point was equipped with a radiac survey meter and, in the event of a breakdown in the communication system, the warning point operator would sound a warning when fall-out registered on the survey meter reached $0 \cdot 3$ röntgens per hour. Warning of the actual fall-out would be sounded by maroon. Distribution of maroons would begin early next year. In addition, fall-out warnings would be given by the BBC's wartime broadcasting system, picked up by transistor radios. (Debate, eivil defence warnings, December 19.) 